\title{
Õpilaste heaolu resilientsus ja mõistestruktuuri areng: erinevused kooliga rahulolu säilitamisel ebameeldivate koolikogemuste ja klassiõpetaja kasvatusstiili taustal
}

\author{
Aivar Ots ${ }^{\text {a }}$ \\ ${ }^{a}$ Tallinna Ülikooli psühholoogia instituut
}

\begin{abstract}
Annotatsioon
Artiklis käsitletakse seoseid õpilaste kognitiivse arengu ja koolis kogetava heaolu vahel, tuginedes kolmanda kuni viienda klassi õpilastega $(N=495)$ tehtud pikiuuringule, millega selgitati koolilaste psühholoogilise resilientsuse seoseid mõistestruktuuri arenguga. Resilientsus tähendab psüühilist toimetulekut stressi ja üleelatud õnnetustega viisil, millega sälitatakse või taastatakse enda heaolu ja tegevusvõime (vt Rutter, 2006; Shiner \& Masten, 2012). Resilientsuse avaldumisena käsitleti uurimuses kooliga rahulolu säilitamist kõrge ebameeldivate tundeelamuste taseme korral. Selliste tundeelamuste taseme määramisel lähtuti asjaomaste kogemuste subjektiivsetest kirjeldustest. Lisaks selgitati õpilaste heaolu ja resilientsuse seoseid klassiõpetaja kasvatusstiiliga. Oletati, et arenguliselt hilisema mõistestruktuuri kasutamine (Toomela, 2003a; Võgotski, 1934/1999) võiks soodustada õpilasel suurema resilientsuse esinemist. Tulemused on oletusega kooskõlas, näidates, et kolme aasta vältel arenguliselt hilisemat mõistestruktuuri kasutanud õpilased säilitasid kõrgema negatiivsete elamuste taseme puhul sagedamini kooliga rahulolu. Samuti leiti, et klassiõpetaja hoolivust väljendavad ja toetavad tegevused soodustavad õpilaste sagedasemat rahulolu kooliga ning psühholoogilist ja käitumuslikku kontrolli taotlevad tegevused sagedasemat rahulolematust. Statistilise andmetöötluse jaoks kasutati konfiguratsioonilisi sagedusanalüüse (von Eye, 1990).
\end{abstract}

Võtmesõnad: psühholoogiline resilientsus, mõistestruktuuri areng, subjektiivne heaolu, põhikool, õpetamisstiilid, negatiivsed tundeelamused

1 Psühholoogia instituut, Tallinna Ülikool, Narva mnt 29, 10120 Tallinn; aivar.ots@ut.ee 


\section{Sissejuhatus}

Artiklis tutvustatakse õpilaste heaolu uuringut, mis korraldati põhikooli kolmandast viienda klassini. Uuringu eesmärk on selgitada, kuidas erineb õpilaste võime säilitada koolis kogetavat heaolu, võttes arvesse nende kooliga seotud ebameeldivaid kogemusi ja kognitiivset arengut. Õpilaste heaoluga seotud koolikeskkonna käsitlemisel lähtutakse õpilaste subjektiivsetest määratlustest ja klassiõpetaja kasvatusstiilist. Õpilaste heaolu on hariduses oluline teema mitmel põhjusel. Ühelt poolt on laste heaolu jagatud väärtus, mis suunab õpetajate, lapsevanemate ja teiste asjaomaste täiskasvanute tegevust laste toimetuleku toetamisel. Teisalt on puudujääke õpilaste heaolus otseselt seostatud õpiedukuse, õpimotivatsiooni, koolist puudumiste ja ka kooli pooleli jätmisega (nt Fallis \& Opotow, 2003; Jonker, 2006; Lee \& Breen, 2007). Väiksemat heaolu võib näiteks seostada tagasihoidlikumate haridussaavutustega, lähtudes hoidumisstrateegiate ja -eesmärkide sagedasemast esinemisest inimestel, kes on oma oludega rahulolematud (Elliot, Thrash, \& Murayama, 2011; Hofer, Busch, \& Kärtner, 2011).

\section{Kooliga rahulolu ja psühholoogilise resilientsuse avaldumine}

Siinne õpilaste heaolu käsitlus lähtub subjektiivse heaolu (subjective wellbeing - vt Diener, 1984; Diener, Suh, Lucas, \& Smith, 1999) uurimistraditsioonist, mis määratleb heaolu indiviidi subjektiivse kogemusena, mis kajastab nii kogetud positiivseid kui ka negatiivseid tundeelamusi. Siinkohal käsitletakse heaoluna nii indiviidi üldist heaolu (rahulolu oma elu kui tervikuga) kui ka heaolu spetsiifilisemates valdkondades (nt rahulolu pereelu või tööga). Uurijad on oletanud, et indiviidi heaolu väljendab kogetud negatiivsete ja positiivsete elamuste tasakaalu, kuigi samas on leitud, et erineva orientatsiooniga elamused on üksteisest võrdlemisi sõltumatud heaolu prognoosijad (Bradburn, 1969; Costa \& McCrae, 1980; Diener \& Emmons, 1984; Emmons \& Diener, 1985). Seega võiks heaolu kohta antud hinnanguid vaadelda kui spetsiifiliste elamuste üldistusi. Kuigi heaolu seostatakse suure hulga erinevate tundeelamustega, ilmnevad enda heaolu hinnangud pigem stabiilsetena (Eid \& Diener, 2004). Samas on osutatud, et heaolu muutumist võiksid enam mõjutada sagedamini kogetavad ja intensiivsemad elamused (Diener, Larsen, Levine, \& Emmons, 1985; Garcia \& Siddiqui, 2009; Ots \& Tago, 2012). Praeguses uuringus on ópilaste koolis kogetavat heaolu käsitletud kooliga rahuloluna, mis ühe valdkondliku heaolu kogemusena peaks kajastama õpilaste tundeelamusi nende jaoks koolina käsitletavas valdkonnas (Ots, 2010; Ots \& Tago, 2012). 
Uuringud on osutanud mitmele asjaolule, mis seostuvad ópilaste heaoluga koolis. Sellised tegurid on näiteks läbisaamine kaasõpilaste ja õpetajatega, õpetajate hoiakud, kooli väärtussüsteem, tõrjumine ja õppetöö korraldus (Fallis \& Opotow, 2003; Jonker, 2006; Lee \& Breen, 2007; Ruus et al., 2007). Kuigi leidub erinevaid koolikeskkonna tunnuseid, mis seostuvad üldiselt õpilaste rahuloluga, on ilmne, et samade asjaolude juures muutuvad mõned õpilased rahulolematuks, kuid teised mitte. Sellist erinevust võiks käsitleda erinevustena psühholoogilises resilientsuses, mis tähistab psüühilist vastupanu riskidele või toimetulekut stressi ja üleelatud õnnetustega, kuid mille korral säilitatakse või taastatakse enda heaolu ja tegevusvõime (vt Masten, Best, \& Garmezy, 1990; Rutter, 2006; Shiner \& Masten, 2012). Resilientsuse käsitluse põhjal saab täheldada erinevusi kooliga rahulolu säilitamisel, kõrvutades õpilaste rahuloluhinnanguid nende negatiivsete koolikogemustega. Just negatiivsed tundeelamused võiksid avaldada survet rahulolematuse ilmnemiseks.

Õpilaste negatiivseid tundeelamusi tingivaid kogemusi saab määratleda mitmeti. Varasemates uuringutes on osutatud koolikeskkonna tunnustele, mis seostuvad üldiselt õpilaste väiksema rahuloluga (nt Fallis \& Opotow, 2003; Lee \& Breen, 2007; Ruus et al., 2007). Sellised uuringud väljendavad mõtteviisi, et võimalik on kindlaks määrata keskkonna tunnused, mis häirivad ühtmoodi erinevate õpilaste heaolu. Suurem resilientsus väljenduks sel juhul siis, kui õpilane säilitab kooliga rahulolu tingimustes, mis üldiselt põhjustavad rahulolematust.

Eesti koolides moodustavad kuni neljanda klassini (kaasa arvatud) õpilaste jaoks olulise osa koolikeskkonnast klassiõpetaja tegevused (nt koolielu korraldus, õpilastega suhtlemise viis, õpetamismeetodid). Seega võiksid klassiõpetajate tegevuse eripärad seostuda erinevustega õpilaste rahulolus. Üks võimalus kirjeldada paljusid tegevusi hõlmavas õpetajatöös ilmnevaid individuaalseid eripärasid on nende iseloomustamine õpetamisstiilide kaudu. Õpetamisstiile võib määratleda mitmeti, näiteks lähtudes erinevustest ainekäsituses, õpetamismeetodite eelistusest või klassi tegevuse juhtimisest ja enda rollist õpetajana (nt Bennet, 1976; Schwartz, Merten, \& Bursik, 1987; Sieber \& Wilder, 1967). Õpetamisstiilide puhul pööratakse tähelepanu teabe edastamise viisidele ja klassi tegevuste organiseerimisele, keskendudes nii õpetamise akadeemilistele kui ka sotsiaalsetele külgedele. Samas ei pruugi just aineõpetust käsitlevad aspektid (nt ainekäsituse või eesmärkide tähenduses) olla laste heaolu uurimisel alati asjakohased.

Õpilaste resilientsuse uurimise seisukohalt võivad osutuda tähtsaks õpetajate tegevuse iseloomustamiseks loodud Baumrindi (1966) kasvatus- 
stiilide tüpoloogia kohandused. Lewini (Lewin, Lippitt, \& White, 1939) juhtimisstiilide käsitlust adapteerides võimaldab see eristada lapsevanemate autoritaarset, autoriteetset ja lubavat kasvatusstiili. Tüpoloogia tugineb kolmele vastandite kategooriale: a) soojus ja tõrjumine, b) struktuur ja kaos, c) autonoomia toetamine ja sundimine (Skinner, Johnson, \& Snyder, 2005). Seejuures on varasematest uuringutest ilmnenud seosed vanemate kasvatusstiili ja laste heaolu vahel. Autoriteetne ja lubav kasvatusstiil seostuvad laste suurema rahuloluga. Autoritaarse stiili puhul on täheldatud lastel väiksemat rahulolu ning ka kohanemis- ja käitumisprobleemide sagedasemat esinemist (nt Raboteg-Saric \& Sakic, 2013; Smith \& Moore, 2013). Kasvatusstiilidest lähtudes on uuritud ka õpetajate juhtimisviise ning nende seoseid õpilaste toimetuleku ja saavutustega koolis, näidates, et autoriteetse stiili rakendamine võib avaldada positiivset mõju õpilaste sotsiaalsele ja akadeemilisele kompetentsusele ning enesehinnangule (vt Skinner et al., 2005; Uibu \& Kikas, 2012; Walker, 2009). Seega võiks arvata, et kasvatusstiilid väljendavad täiskasvanu tegevuse olulisi tunnuseid, mis on seotud lapse heaoluga. Lisaks võib oletada, et neis klassides, kus suurema osa igapäevasest õppetööst viib läbi klassiõpetaja, avaldab tema kasvatusstiil mõju õpilaste heaolule. Seega võiks kasvatusstiilide käsitluse põhjal määratud klassiõpetaja tegevuse tunnused sobida koolikeskkonna indikaatoriteks, mille abil saab hinnata õpilaste rahulolu resilientsust.

Ainult koolikeskkonna teatud omaduste põhjal õpilaste negatiivsete elamuste iseloomustamine võib piirata nii kooliga seotud negatiivsete tundeelamuste kui ka resilientsuse esinemise adekvaatsust. Sarnases situatsioonis õpilased võivad kogeda erinevaid tundeelamusi. Asjaolud, mida peetakse enda jaoks tähtsaks ja mis tingivad tugevamaid tundeelamusi, võivad olla erinevad. Samas kui ühele õpilasele on väga tähtsad tema ópitulemused, muretseb teine rohkem oma klassisuhete pärast. Kooliga rahulolu häirivate tundeelamuste määratlemisel võiks keskenduda just selliseid elamusi hõlmavatele kogemustele, arvestades samas, et keskkonnategurid, millest need tulenevad, erinevad õpilasiti. Kooli kohta antavate rahuloluhinnangute kujunemist selles kontekstis võiks seletada Lewini (1939) seisukohaga, et indiviid ei reageeri oma käitumisega otseselt keskkonna tunnustele, vaid pigem nende psühholoogilisele kajastusele (nn enda elamise ruumile - life-space). Seega võiks õpilaste kooliga seotud tundeelamusi asjakohasemalt iseloomustada nende endi subjektiivselt määratletud kogemused. Selline käsitlusviis aitab järjepidevamalt lähtuda heaolu subjektiivsusest ning autentsemalt kajastada asjaolusid, mis avaldavad mõju õpilaste heaolule koolis. 


\section{Psühholoogiline resilientsus ja kognitiivne areng}

Siinne uuring keskendub õpilase kognitiivse arengu ja psühholoogilise resilientsuse avaldumise seostele kooliga rahulolu kontekstis. Kognitiivse arengu käsitlemisel tuginetakse mõistestruktuuri arengu teooriale (Toomela, 2003a; Võgotski, 1934/1999), mis käsitleb arengu keskse mõõtmena tunnetustegevuses üleminekuid ühelt mõiste moodustamise viisilt kvalitatiivselt teistsugusele mõiste moodustamise viisile. Selliseid muutusi kirjeldatakse mõistestruktuuri alusel, määrates, millist tüüpi tunnuste ja nendevaheliste seoste põhjal moodustub märkide tähendus. Kuigi eristatakse mitmeid mõistestruktuuri tüüpe, on selles uuringus keskendutud üleminekule tavamõistete kasutamiselt teadusmõistete kasutamisele.

Tavamõisted on arenguliselt varasemad, hõlmates märgiliselt vahendatud mõtlemises mõistete kasutamist keskkonnas esinevate nähtuste ja nendevaheliste seoste ulatuses. Tavamõisteline mõtlemine kujuneb etapiti (nt Toomela, 2003a; Võgotski, 1934/1999) alates lapse poolt esimeste märkide kasutuselevõtust, mille tähendused tuginevad objektiks oleva nähtuse meeleliselt kogetavatele tunnustele. Need tunnused ei kirjelda nähtusi süstemaatiliselt ning väikelaps võib neid korduvalt vahetada (jänes võib ühes olukorras olla aua (koer), sest ta on karvane ja tuttava koeraga sama mõõtu, kuid teises olukorras ei ole ta aua, sest ta ei haugu). Õppides keele abil keskkonda ja enda tegevust määratlema, muutuvad tavamõistes märgi ja selle objekti vastavust iseloomustavad tunnused püsivaks ning objekt süstemaatilisemalt eristatavaks. Kuid ka hilisemaid tavamõiste vorme iseloomustab tähendus, mis kajastab objektide tunnuseid ja nende seoseid keskkonnas esineval kujul (nt koolis käiakse óppimas, kaalikas ja porgand kuuluvad kokku, sest nad kasvavad aias). Seega on tavamõisteline mõtlemine määratud keskkonnaga, milles indiviid viibib, ning mõtlemine nähtustest, mis ületavad isiklikke kogemusi, on takistatud.

Teadusmõistete puhul luuakse tähendus, lähtudes keelesisestest seostest teiste mõistetega. Tunnused, mille alusel mõistetevahelised seosed määratletakse, on süstemaatilised ning ei põhine keskkonnast pärinevatel tunnustel ega nende seostel (nt kool on haridusasutus, kaalikas ja porgand kuuluvad kokku, sest nad on juurviljad). Teadusmõiste struktuur on hierarhiline, sest mõiste tähendus määratletakse kategooriana, kuhu see kindla kriteeriumi põhjal kuulub. Teadusmõistete kasutuselevõtt eeldab kogemusega seotud teadmiste üldistumist ja abstraheerumist keskkonnaga seotud kogemustest. Arengulised muutused mõistestruktuuris põhinevad kultuurilisel interaktsioonil, mille käigus indiviid internaliseerib uusi märgiliselt vahendatud kultuurilisi mehhanisme. Teadusmõistete kujunemist on seostatud spetsiifiliste tegevustega, mis on omased koolis 
õppimisele (Luria, 1976; Võgotski, 1978). Luria (1976) osutab, et koolis õppimine aitab probleemilahendamisel kujuneda eriliseks teoreetiliseks tegevuseks, mis on keeleline ja keskkonnast sõltumatu. Seega kasvab mõistestruktuuri arenguga indiviidi tõhusus teabe töötlemisel ja kohandumisel erinevate olukordadega.

Mõistestruktuuri tüüpide arengulisi erinevusi on tänapäeva arengupsühholoogias korduvalt kirjeldatud (nt Kikas, 1998; Nelson, 2003; Toomela, 2003a). Siinse uuringu seisukohalt on tähtis, et uus mõistestruktuur ei too kaasa lapse mõtlemise muutumist korraga. Mõtlemise heterogeensus (Tulviste, 1988) osutab, et uued mõistestruktuurid ei asenda varasemaid, vaid lisanduvad neile. Seega olukorras, kus õpilane suudab kooliülesannete lahendamisel kasutada teadusmõisteid, võib ta nii muudes valdkondades kui ka kooliõpingutes jätkata tavamõistete kasutamist. Võimalik, et teadusmõistete kasutamine ei ole algul väga järjepidev ning mõistestruktuuri eelistuse kujunemine võtab aega.

Õpilaste mõistestruktuuri arengutaseme määramist võivad raskendada pseudomõisted. Võgotski (1934/1999) märgib, et lapsed ei kujunda mõisteid sageli spontaanselt, vaid eeskujude varal. Seetõttu kujunevad pseudomõisted, mille puhul kirjeldatakse mõiste tähendust teadusmõiste vormis, kuid mõistet kasutatakse või määratletakse spontaanselt tavamõistena. Näiteks on Kikas (1998) leidnud, et lapsed, kes koolis õpivad astronoomiliste nähtuste (nt aastaaegade vaheldumise) teaduslikke selgitusi, võivad ühtlasi kasutada samade nähtuste selgitamiseks tavamõistelisi teadmisi. Seega võiks arvata, et põhikoolis, mille jooksul õpilastel üldiselt areneb võime kasutada teadusmõisteid, on teadusmõistete olemasolu ja kasutamise ulatust mõneti keerukas hinnata, arvestades nii nende kasutamise situatsioonilist isoleeritust, ebajärjepidevust kui ka pseudomõistete esinemist.

Mõistestruktuuri arengu asjakohasust õpilaste heaolu uurimisel näitab varasem uuring (Ots, 2010), milles leiti, et ebameeldivate kogemuste puhul säilitasid kooliga rahulolu paremini ópilased, kelle isiksus oli viiefaktorilises isiksuse teoorias (McCrae \& Costa, 1996) määratletud omaduste poolest enam diferentseerunud (erinevad omadused olid teiste lastega võrreldes korraga tugevamalt väljendunud). Seda diferentseerumist tõlgendati kui indiviidi arengut väljendavat tunnust (vt Werner \& Kaplan, 1956), mille erinevusi analüüsiti õpilaste mõistestruktuuri arengu kontekstis. Kooskõlas uuringutega, mis on korduvalt seostanud isiksuseomaduste struktuuri ja selle mitmekesistumist mõistestruktuuri arenguga (Arro, 2010, 2012; Toomela, 2003b), leiti positiivne seos õpilaste isiksuse diferentseerumise ja teadusmõistete kasutamise vahel. Eeldades, et 
rahulolu säilitamisega seostunud isiksuse diferentseerumine võiks kajastada mõistestruktuuri arengut, võis oletada, et teadusmõisteid kasutavatel õpilastel võib esineda teiste ees eeliseid nii ebameeldivate keskkonnaaspektide määratlemisel enda jaoks kohasena kui ka ebameeldivate olukordade kompenseerimiseks meeldivate kogemuste leidmisel. Seega ei tõlgendatud psühholoogilise resilientsuse esinemist mitte niivõrd isiksuseomaduste endi, kuivõrd komplekssema ja igapäevaseid kogemusi ümberkorraldava teabetöötlemisvõime alusel. Seega võiks arvata, et teadusmõistete kasutamine seostub ka otseselt tõhusama heaolu säilitamisega. Ühtlasi võiks see seos aidata leida õpilaste heaolu toetamiseks sobivaid viise, arvestades ka seda, et mõistestruktuuri arengut on seostatud õppimise ja koolihariduse tasemega (Luria, 1974; Toomela, 2008; Võgotski, 1978).

\section{Uurimisküsimused}

Uuringu eesmärk oli selgitada õpilaste mõistestruktuuri arengu seost võimega säilitada kooliga rahulolu seal kogetud negatiivsete tundeelamuste kontekstis. Selle eesmärgi järgimiseks esitati kaks uurimisküsimust:

1) millised on õpilaste kooliga rahulolu seosed nende kogetud negatiivsete tundeelamustega, lähtudes subjektiivselt määratletud kogemustest ja koolikeskkonna tunnustest (klassiõpetaja kasvatusstiili tunnuste alusel)?

2) milline on õpilaste mõistestruktuuri arengu seos kooliga rahulolu säilitamisel avalduva psühholoogilise resilientsusega, lähtudes kogetud negatiivsetest tundeelamustest ja klassiõpetaja kasvatusstiili tunnustest?

Varasemate uuringute tulemuste (Ots, 2010; Ots \& Tago, 2012) põhjal ning lähtudes arusaamast, et indiviidi kogetav heaolu kajastab suurt hulka erinevaid tundeelamusi ja väiksem heaolu seostub negatiivsete tundeelamustega (Bradburn, 1969; Costa \& McCrae, 1980; Diener \& Emmons, 1984; Emmons \& Diener, 1985), oletati, et kooliga rahulolu võiks olla kolme aasta jooksul väiksem õpilastel, kes kogevad koolis enam negatiivseid tundeelamusi. Varasema uuringu tulemustele (Ots, 2010) tuginedes oletati samuti, et leidub suurema resilientsusega õpilasi, kes hoolimata kõrgest negatiivsete tundeelamuste tasemest on kooliga rahulolevad. Sama uuringu tulemused osutasid ka seostele mõistestruktuuri arengu ja isiksuse diferentseerumise ning isiksuse diferentseerumise ja kooliga rahulolu resilientsuse vahel. Arvestades, et mõistestruktuuri areng mitmekesistab teabetöötlemise võimekust ja aitab tõhusamalt lahendada erinevaid 
probleeme (Luria, 1976; Võgotski, 1934/1999), oletati, et teadusmõistete süstemaatilisem kasutamine kolme aasta jooksul iseloomustab õpilasi, kes säilitavad ka oma rahulolu kooliga tõhusamalt.

\section{Meetod}

\section{Valim}

Uuring tehti kahe mitmeaastase uurimisprojekti osana. Uuringusse kaasati projektide valimitest 495 õpilast (58\% naissoost), kes kolmandast viienda klassini täitsid igal aastal kooliga rahulolu küsimustiku ja mõistestruktuuri testi. Õpilaste vanus jäi vahemikku 8-10 aastat $(M=8,97)$. Üle Eesti osales uuringus 33 eesti õppekeelega põhikooli, mille hulgas olid esindatud nii suuremate kui ka väiksemate linnade ning maapiirkondade koolid. Iga õpilase puhul oli uuringus osalemise eeltingimus lapsevanema informeeritud nõusolek.

\section{Mõõtevahendid}

Kooliga rahulolu ja kooliga seotud negatiivsete tundeelamuste tase. Õpilaste kooliga rahulolu hinnanguid ja subjektiivseid kirjeldusi koolis kogetud negatiivsete tundeelamuste kohta koguti kooliga rahulolu küsimustikuga (Ots, 2010). Selles küsimustikus kirjeldatakse kooliga rahulolu kui õpilase valdkonnaspetsiifilist hinnangut iseenda heaolule, lähtudes küsimusele „Kas Sulle meeldib koolis käia?” antud vastustest. Positiivseid vastuseid käsitleti kooliga rahulolu väljendavatena ja need kodeeriti muutuja loomisel väärtusega üks. Negatiivseid vastuseid käsitleti rahulolematusele osutavatena ja need kodeeriti väärtusega null (kooliga oli rahul $76 \%$ õpilastest kolmandas, $63 \%$ neljandas ja $62 \%$ viiendas klassis).

Kooliga seotud negatiivsete tundeelamuste (NT) kohta andmete kogumiseks paluti õpilastel nimetada kuni kolm asja, mis neile koolis ei meeldi (nt kui õpetajad annavad tunnitööd liiga palju; vara tõusta; klassis on raske óppida, kui kõik karjuvad; kaklemine). Iga esitatud asjaolu kohta paluti vastajal hinnata, kuidas see on teda mõjutanud. Kolmandas klassis kasutati hinnangute andmiseks kolme vastusevarianti: 1) Ma olen sellele mõelnud, 2) See teeb mind kurvaks, 3) Ma olen selle pärast nutnud. Neljanda klassi andmete kogumisel lisati veel üks vastusevariant: 4) See teeb mind vihaseks. Viiendas klassis asendati kolmas ja neljas vastusevariant valikuga 5) Ma ei taha selle pärast kooli minna. Neljandas klassis muudeti vastusevariante eesmärgiga laiendada vastajate võimalusi identifitseerida kogetud 
tugevamaid emotsioone käitumise kirjelduste kaudu. Viienda klassi jaoks muudeti skaalat, lähtudes uurimisprojektile seatud eesmärgist määrata kindlaks tegurid, mis võiksid seostuda õpingute varajase katkestamisega.

Muutujate loomisel eri kooliaastate kohta kasutati NT intensiivsuse mõõtmiseks järgmist kodeerimisskaalat: esimese vastusevariandi valikut peeti nõrga tundeelamuse väljenduseks ja see kodeeriti väärtusega üks; teise variandi valikut käsitleti mõõduka intensiivsusega tundeelamuse väljendusena ja see kodeeriti väärtusega kaks; igal aastal kolmanda või neljanda vastusevariandi valimist käsitleti tugeva tundeelamuse väljendusena ja see kodeeriti väärtusega kolm. Seega loodi iga aasta kohta muutuja, mille väärtused said varieeruda vahemikus null kuni üheksa (vt tabel 1). Edasistes sagedusanalüüsides on neid muutujaid ümber kodeeritud, nt on õpilasi rühmitatud algsete muutujate mediaanväärtuse, tertsiilide või kvartiilide alusel. Ümberkodeerimisel on loodavate kategooriate jaotused valitud analüüside jaoks, leides väärtuste vahemikud, mille puhul eristuvad olulised õpilaste tunnuste kombinatsioonid (kodeerimisel kasutatud kriteeriumid on esitatud iga analüüsi tulemuste juures).

Mõõdiku varasemal kasutamisel (Ots, 2010; Ots \& Tago, 2012) on leitud neljanda ja viienda klassi õpilastel negatiivne seos kooliga rahulolu ja NT taseme vahel. Samuti on täheldatud aasta jooksul kooliga rahulolu muutumist kooskõlas muutustega NT tasemes (Ots \& Tago, 2012). Niisamuti on leitud (Ots \& Tago, 2012) positiivne seos kooliga rahulolu ja globaalse enesehinnangu vahel ning näidatud, et kombinatsioon kooliga rahulolust ja madalast NT tasemest esineb tüüpiliselt koos kõrge globaalse enesehinnanguga ning kombinatsioon kooliga rahulolematusest ja kõrgest NT tasemest koos madala globaalse enesehinnanguga. Need seosed globaalse enesehinnanguga, mida on uuringute põhjal käsitletud üldisele heaolule väga lähedase konstruktina (vt Rosenberg, Schoenbach, Schooler, \& Rosenberg, 1995), võiksid tagada ühel küsimusel põhineva kooliga rahulolu hindamise ja ka terve mõõtevahendi valiidsuse. Negatiivne seos kooliga rahulolu ja NT taseme vahel on ka kooskõlas mõõtevahendi loomisel aluseks olnud teoreetiliste kaalutlustega.

Isegi kui kahel aastal leitud seosed negatiivsete tundeelamuste, rahulolu ja enesehinnangu vahel viitavad, et osaliselt muudetud vastusevariantidega NT määramise ülesande tulemused esinevad sarnastes seostes (st suured skoorid seostuvad rahulolematusega ja väikesed rahuloluga), ei saa eri aastate tulemusi pidada samatähenduslikeks. Seega on NT ja kooliga rahulolu vaheliste seoste pikilõikelisel hindamisel esmalt tuginetud eri aastate läbilõikeliste tunnuste kombinatsioonide vaheliste seoste selgitamisele. Kui analüüsis ilmnesid olulised seosed aastate vältel, 
kasutati edasistes analüüsides vastavaid kombinatsioone kolme aasta jooksul ilmnevaid muutusi iseloomustavate trajektooridena.

Mõistestruktuur. Õpilaste mõistestruktuuri arengut kirjeldati Luria (1979) teooriale tugineva mõistestruktuuri testi (Toomela, 2003b) põhjal, mis hõlmab kahte teineteist täiendavat osa. Esimese osa kolmes ülesandes tuli vastajal defineerida mõisteid (nt Mida tähendab õppimine?). Teises osas tuli vastajal kaheksas ülesandes selgitada, miks esitatud sõnad kuuluvad omavahel kokku (nt kombinatsioonid sõnadest ema, laps, õpetaja). Lähtudes tava- ja teadusmõisteid iseloomustavatest tunnustest (Luria, 1979; Toomela, 2003b), määratleti õpilaste vastused igas ülesandes kas tavamõistena (kodeeriti väärtusega null) või teadusmõistena (kodeeriti väärtusega üks). Vastaja testitulemus saadi kõigi ülesannete skooride liitmisel (vt tabel 1). Arvestades, et teadusmõisteline mõtlemine on valimi vanuserühmas veel piiratud ja ebapüsiv ning vastused võivad hõlmata ka pseudomõisteid, eristati analüüside jaoks teistest ainult need õpilased, kes kolme aasta vältel olid süstemaatiliselt kasutanud teadusmõisteid. Seega loodi kolme aasta muutujate põhjal uus muutuja, kus eristati ópilased, kes kasutasid vastamisel teadusmõisteid igal aastal (kodeeriti väärtusega üks, $25 \%$ valimist), nendest õpilastest, kes ei teinud seda kordagi või tegid seda ühel või kahel mõõtmisel (kodeeriti väärtusega null, 75\% valimist, sh 9\% - ainult tavamõistete kasutajad; 18\% - need, kes kasutasid ühel aastal teadusmõisteid, kuid järgneval aastal ainult tavamõisteid; $48 \%$ - need, kes hakkasid pärast tavamõistete kasutamist alates neljandast või viiendast klassist teadusmõisteid kasutama).

Tabel 1. Õpilaste muutujate kirjeldus

\begin{tabular}{c|c|c|c|c|c}
\hline Muutuja & $M$ & SD & Min & Max & $N$ \\
\hline \multicolumn{5}{l}{ Kooliga seotud negatiivsed tundeelamused } \\
\hline 3. kl & 3,6 & 2,24 & 0 & 9 & 495 \\
$4 . \mathrm{kl}$ & 5,8 & 2,34 & 0 & 9 & 495 \\
$5 . \mathrm{kl}$ & 4,9 & 2,28 & 0 & 9 & 489 \\
\hline Mõistestruktuur & \multicolumn{5}{l}{} \\
\hline 3. kl & 0,7 & 1,19 & 0 & 8 & 489 \\
4. kl & 1,6 & 1,58 & 0 & 9 & 488 \\
$5 . \mathrm{kl}$ & 1,7 & 1,59 & 0 & 10 & 489 \\
\hline
\end{tabular}


Klassiópetaja kasvatusstiili kui koolikeskkonda õpilastest sõltumatult kirjeldavat tunnust iseloomustati klassiruumi juhtimispraktikate küsimustiku (Hinn, 2009; vt teoreetiline selgitus Uibu \& Kikas, 2012) põhjal, kus vastajal tuleb viiepallisel skaalal ( 1 - mitte kunagi ... 5 - alati) määrata, kui sageli ta kasutab küsimustikus kirjeldatud käitumisviise. Õpetaja kasvatusstiili eripärade esiletoomiseks hõlmab küsimustik viit alamskaalat. Neist on kasutatud kolme, millel on varem leitud seos õpilaste rahuloluga (Ots, 2010). Psühholoogilise kontrolli skaala sisaldab kolme väidet, mis kirjeldavad õpilaste kontrollimist ópetaja pettumuse väljendamise ja süütunde tekitamise kaudu (Cronbachi $\alpha=0,68$ ). Käitumusliku kontrolli skaala hõlmab kahte väidet, mis käsitlevad õpilaste kuulekuse tähtsustamist (Cronbachi $\alpha=0,55)$. Toetuse ja hoolivuse skaala koosneb kaheksast väitest, mis kajastavad positiivseid suhteid õpilastega (Cronbachi $\alpha=0,62$ ). Sagedusanalüüside tegemiseks kodeeriti kõigi kolme alamskaala individuaalsed skoorid (õpetaja poolt alamskaala väidete puhul Likerti skaalal valitud väärtuste aritmeetilised keskmised), lähtudes alamskaalade mediaanväärtusest. Saadi uued muutujad, mille puhul mediaani ületavad skoorid määrati antud kasvatusstiili tunnuse esinemise kõrge tasemena (kodeeriti väärtusega üks) ning ülejäänud madala tasemena (kodeeriti väärtusega null).

\section{Protseduur}

Artikkel põhineb kolmeaastasel pikiuuringul, mille käigus koguti samadelt õpilastelt andmeid kolmanda, neljanda ja viienda klassi sügisel. Koolides viidi läbi rühmatestimine, kus õpilased täitsid klasside kaupa 45 minuti jooksul neile antud küsimustikud. Uuringus osalenud klasside klassiõpetajad täitsid klassiruumi juhtimispraktikate küsimustikud individuaalselt, kui nende õpilased olid neljandas klassis.

\section{Andmeanaliuiis}

Uuring selgitab õpilaste individuaalseid erinevusi, keskendudes spetsiifiliste omaduste kombinatsioonidele indiviiditasandil. Seetõttu põhinevad uurimistulemused indiviidikesksel käsitlusviisil (person-oriented approach, Bergman \& Magnusson, 1997; vt Magnusson, 2001) - metodoloogilisel suunal, mis käsitleb indiviidi kompleksse dünaamilise süsteemina ning taotleb selle protsesside ja arengu kirjeldamist terviklikuna. Et mõista indiviidi toimimist, on vaja pöörata tähelepanu individuaalsete omaduste ainulaadsetele mustritele. Selleks, et analüüside käigus säiliksid individuaalselt erinevad omaduste mustrid, üldistamata neid rühmatasandil, 
on siinkohal kasutatud konfiguratsioonilist sagedusanalüüsi (KSA, vt von Eye, 1990). See meetod võimaldab hinnata, kas erinevate mustritega juhtumeid on esinenud oluliselt sagedamini (ilmneb tü̈̈p) või harvem (ilmneb antitüüp), kui see võiks toimuda juhuslikult. Sagedustabelites tüüpide ja antitüüpide määramiseks kasutati statistilise andmeanalüüsi programmi SLEIPNER 2.1 moodulit EXACON (Bergman \& El-Khouri, 2002). Tunnuste mustrite olulisust hinnati binomiaalse testiga (täpne test). Kahe dihhotoomse muutuja seost on hinnatud läbivalt hii-ruut-testiga.

\section{Tulemused}

\section{Kooliga rahulolu ja negatiivsed tundeelamused}

Et vastata esimesele uurimisküsimusele, selgitati, kuidas on õpilaste rahulolu kooliga seotud nende kogetud negatiivsete tundeelamustega, lähtudes subjektiivselt määratletud ebameeldivatest kogemustest ja klassiõpetaja kasvatusstiilist.

Subjektiivselt määratletud NT ja kooliga rahulolu seost uuriti esmalt läbilõikeliselt - iga aasta vastavate muutujatega tehti KSA. Neis analüüsides jaotati kõik juhtumid NT skooride põhjal kolme rühma: 1) madalam tase - esimese kvartiili juhtumid, 2) keskmine tase - teise ja kolmanda kvartiili juhtumid, 3) kõrgem tase - neljanda kvartiili juhtumid. Saadud tulemused (vt tabel 2) näitavad, et neljandas ja viiendas klassis eristusid tüübina õpilased, kelle rahulolematus kooliga esineb koos kõrge NT tasemega (1. ja 5. muster). Neljandas klassis moodustus tüüp rahulolevatest õpilastest, keda iseloomustas ühtlasi madal NT tase (2. muster). Nendes klassides leitud antitüüpe võib tüüpidega kooskõlalisteks pidada: mõlemal aastal on vähem tõenäolisteks kombinatsioonideks nii kooliga rahulolu esinemine kõrge NT tasemega (4. ja 8. muster) kui ka rahulolematuse esinemine NT madala tasemega (3. ja 6. muster). Kolmanda klassi puhul olulisi tüüpe ja antitüüpe ei eristunud, kuigi leiti tendents sellise tüübi esinemiseks, kuhu kuuluvad rahulolematud ja kõrge NT tasemega õpilased $\left(f_{o}=49, f_{e}=39, p<0,07\right)$. 
Tabel 2. Läbilõikeliste KSAde tulemused: kooliga rahulolu ja negatiivsed tundeelamused

\begin{tabular}{|c|c|c|c|c|}
\hline $\mathrm{Nr}$ & $\begin{array}{l}\text { Kooliga } \\
\text { rahulolu }\end{array}$ & $\begin{array}{l}\text { Negatiivsete } \\
\text { elamuste tase }\end{array}$ & $\%$ valimist & $\begin{array}{l}\text { Esinenud ja oodatud } \\
\text { sageduse suhe }\end{array}$ \\
\hline \multicolumn{5}{|c|}{ 4. klass $(N=495)$} \\
\hline \multicolumn{5}{|c|}{ Tüübid } \\
\hline 1 & Ei ole rahul & Kõrge & 12,7 & 1,31 \\
\hline 2 & On rahul & Madal & 16,6 & 1,20 \\
\hline \multicolumn{5}{|c|}{ Antitüübid } \\
\hline 3 & Ei ole rahul & Madal & 5,1 & 0,64 \\
\hline 4 & On rahul & Kõrge & 13,9 & 0,82 \\
\hline \multicolumn{5}{|c|}{ 5. klass $(N=489)$} \\
\hline \multicolumn{5}{|c|}{ Tüübid } \\
\hline 5 & Ei ole rahul & Kõrge & 14,9 & $1,64^{*}$ \\
\hline \multicolumn{5}{|c|}{ Antitüübid } \\
\hline 6 & Ei ole rahul & Madal & 9,8 & 0,79 \\
\hline 7 & Ei ole rahul & Keskmine & 13,1 & 0,8 \\
\hline 8 & On rahul & Kõrge & 9,2 & $0,61^{*}$ \\
\hline
\end{tabular}

Märkused. Tabelis on toodud mustrid, mille olulisus on vähemalt $5 \%$ tasemel. * - muster on oluline $(p<0,05)$ ka Bonferroni teisenduse korral.

Seega osutavad KSAde tulemused kahe vanema klassi puhul oletatud kooskõlale kõrge NT taseme ja kooliga rahulolematuse vahel. Kolmanda klassi puhul sellist vastavust toetavaid olulisi tulemusi ei leitud, olgugi et tendentsi sellise tulemuse esinemise suunas täheldati. Kuigi tüübid ja antitüübid kajastavad ootuspäraseid seoseid kooliga rahulolu ja kooliga seotud ebameeldivate kogemuste vahel, näitab mustrite jaotus, et on ka palju õpilasi, keda iseloomustab nende tunnuste teistsugune seos (sh rahulolu koos kõrge negatiivsete tundeelamuste tasemega). Neljandas klassis moodustavad tüüpidest ja antitüüpidest väljajäävad juhtumid 52\%, viiendas klassis $53 \%$ valimist.

Järgmiseks uuriti õpilaste NT ja kooliga rahulolu seoseid pikilõikeliselt. Kuna aastati võis NT skooride tähendus varieeruda, siis analüüsiti kolme aasta rahulolu ja NT läbilõikeliste mustrite vahelisi vastavusi. Analüüsi ettevalmistamisel määrati kõigi juhtumite jaoks kõrge ja madal NT tase iga aasta kohta muutujate mediaanväärtuse alusel (madal tase - skoor mediaanist väiksem või sellega võrdne, kõrge tase - skoor mediaanist suurem). Seega kasutati iga aasta kohta nelja kategooriaga muutujat: 1) kooliga rahulolematu ja madal NT tase, 2) kooliga rahulolematu ja 
kõrge NT tase, 3) kooliga rahulolev ja madal NT tase, 4) kooliga rahulolev ja kõrge NT tase. Ajalise järjepidevuse säilitamiseks kasutati kahte KSAd. Esimese KSA puhul analüüsiti seoseid kolmanda ja neljanda klassi mustrite vahel. Teise KSA jaoks koondati esmalt kolmanda ja neljanda klassi mustrid üheks muutujaks, mille 16 kategooriat väljendasid rahulolu ja NTd ning nendevahelise vastavuse muutumist aasta jooksul. Seejärel analüüsiti KSA abil uue muutuja kategooriate vastavusi viienda klassi rahulolu ja negatiivsete tundeelamuste mustritega, et selgitada, millised muutused lisanduvad eelneva aasta omadele.

Tulemused (vt tabel 3) osutavad, et nii kolmandast neljanda klassini kui ka edasi viienda klassini moodustasid tüübi õpilased, kes on kooliga rahul ja kellel on madal NT tase (1. ja 13. muster). Samuti moodustub läbi kolme aasta tüüp rahulolematutest õpilastest, kellel on kõrge NT tase (3. ja 15. muster). Nende tüüpide kõrval esineb kolmel aastal tüüp, kuhu kuuluvad kõrge NT tasemega rahulolevad õpilased (2. ja 14. muster). Seega eristusid olulise alarühmana õpilased, keda võiks iseloomustada suurem psühholoogiline resilientsus. Peale nende mustrite ilmnes nii esimese kahe aasta kui ka kõigi kolme aasta tulemuste põhjal mitmeid tüüpe, mis kajastavad rahulolu ja kogetud elamuste vastavuse muutumist ajas. Arvestades õpilaste arengut, muutusi koolikeskkonnas ning õpilaste suhetes koolikeskkonnaga, võiks selliseid üleminekuid pidada ootuspärasteks. Näiteks võiks juba madala NT taseme korral esinev rahulolematus säilida või süveneda, kui NT tase tõuseb (5. muster). Samuti võiksid õpilased, kes säilitasid kõrge NT puhul rahulolu oma kooliga, olla endiselt rahulolevad, kui selliste kogemuste hulk väheneb (17. muster).

Mõlemas analüüsis leitud antitüübid osutavad vähem tõenäolisematele üleminekutele kooliga rahulolu ja NT taseme vastavustes. Nii on antitüüpideks mustrid, kus parem NT taluvus asendub järgneval aastal halva taluvusega (õpilane on rahulolematu madala NT taseme kontekstis, 6. ja 23. muster, vt ka 7. ja 24. muster).

Seega osutavad ka pikianalüüside tulemused vastavuses püstitatud oletusega, et kooliga rahulolematus ja selle püsivus seostuvad kõrge NT tasemega. Rahulolevamad on õpilased, kellel on kooliga seoses vähem ebameeldivaid elamusi. Neisse tüüpidesse kuulus neljanda klassi andmete põhjal 25\% ja kolme aasta jooksul 13\% uuritud õpilastest. Samas kolmanda klassi andmete puhul olulisi vastavusi õpilaste NT taseme ja rahulolu vahel ei täheldatud. Siinkohal on tähtis, et oluliselt eristuva alarühma moodustasid õpilased, kes säilitasid kooliga rahulolu negatiivsete tundeelamuste püsivalt kõrge taseme korral. Selline kombinatsioon on kooskõlas seatud oletusega, et leidub õpilasi, kelle resilientsus on enda negatiivsete elamuste suhtes teistega võrreldes suurem. 
Tabel 3. Pikilõikeliste KSAde tulemused: õpilaste rahulolu kooliga ja negatiivsete elamuste taseme vastavus kolmandast viienda klassini

\begin{tabular}{|c|c|c|c|c|c|c|c|c|}
\hline \multirow[t]{3}{*}{$\mathrm{Nr}$} & \multicolumn{6}{|c|}{ Kooliga rahulolu ja negatiivsete elamuste taseme mustrid } & \multirow{3}{*}{$\begin{array}{c}\% \\
\text { vali- } \\
\text { mist }\end{array}$} & \multirow{3}{*}{$\begin{array}{c}\text { Esinenud } \\
\text { ja oodatud } \\
\text { sageduse } \\
\text { suhe }\end{array}$} \\
\hline & \multicolumn{2}{|c|}{$3 . \mathbf{k l}$} & \multicolumn{2}{|c|}{ 4. kl } & \multicolumn{2}{|c|}{$5 . \mathrm{kl}$} & & \\
\hline & $\begin{array}{l}\text { Rahul- } \\
\text { olu }^{\mathrm{a}}\end{array}$ & $\begin{array}{c}\text { Negatiivsed } \\
\text { elamused }^{\mathbf{b}}\end{array}$ & $\begin{array}{c}\text { Rahul- } \\
\text { olua }^{\text {o }}\end{array}$ & $\begin{array}{c}\begin{array}{c}\text { Negatiivsed } \\
\text { elamused }\end{array} \\
\end{array}$ & $\begin{array}{l}\text { Rahul- } \\
\text { olua }^{\text {a }}\end{array}$ & $\begin{array}{c}\begin{array}{c}\text { Negatiivsed } \\
\text { elamused }\end{array} \\
\end{array}$ & & \\
\hline \multicolumn{9}{|c|}{ 3. ja 4. klassi mustrid $(N=495)$} \\
\hline \multicolumn{9}{|c|}{ Tüübid } \\
\hline 1 & + & - & + & - & & & 18,4 & $1,36^{*}$ \\
\hline 2 & + & + & + & + & & & 14,8 & $1,41^{*}$ \\
\hline 3 & - & + & - & + & & & 6,1 & $1,95^{*}$ \\
\hline 4 & - & + & - & - & & & 3,0 & 2,1 \\
\hline 5 & - & - & - & + & & & 5,9 & $2,01^{*}$ \\
\hline \multicolumn{9}{|c|}{ Antitüübid } \\
\hline 6 & + & + & - & - & & & 2,0 & 0,55 \\
\hline 7 & + & + & - & + & & & 5,7 & 0,71 \\
\hline 8 & + & - & - & + & & & 7,3 & 0,67 \\
\hline 9 & - & + & + & - & & & 1,0 & $0,26^{*}$ \\
\hline 10 & - & + & + & + & & & 2,4 & 0,59 \\
\hline 11 & - & - & + & - & & & 2,0 & 0,56 \\
\hline 12 & - & - & + & + & & & 1,8 & 0,47 \\
\hline \multicolumn{9}{|c|}{$\begin{array}{c}\text { Samasse muutujasse koondatud 3. ja } 4 \text {. klassi mustrid ning } \\
\text { muutuja 5. klassi mustritega }(N=489)\end{array}$} \\
\hline \multicolumn{9}{|c|}{ ( } \\
\hline 13 & + & - & + & - & + & - & 9,4 & 1,60 \\
\hline 14 & + & + & + & + & + & + & 7,6 & 1,72 \\
\hline 15 & - & + & - & + & - & + & 3,9 & $2,54^{*}$ \\
\hline 16 & + & - & - & + & - & + & 3,9 & 2,12 \\
\hline 17 & + & + & + & - & + & - & 5,5 & 1,76 \\
\hline 18 & + & + & - & - & - & - & 0,8 & 3,10 \\
\hline 19 & + & - & + & + & + & + & 6,5 & 1,62 \\
\hline 20 & + & - & - & + & - & - & 2,1 & 2,16 \\
\hline 21 & - & - & + & - & + & + & 1,4 & 2,38 \\
\hline 22 & - & - & - & - & - & + & 1,2 & 2,41 \\
\hline \multicolumn{9}{|c|}{ Antitüübid } \\
\hline 23 & + & + & + & + & - & - & 0,6 & 0,32 \\
\hline 24 & + & + & + & + & - & + & 2,3 & 0,60 \\
\hline 25 & + & + & + & - & - & + & 1,0 & 0,43 \\
\hline 26 & + & - & + & + & - & - & 0,6 & 0,35 \\
\hline 27 & + & - & + & - & - & + & 1,4 & $0,32^{*}$ \\
\hline 28 & + & - & - & + & + & - & 0,8 & 0,34 \\
\hline 29 & + & - & + & - & + & + & 0,6 & 0,28 \\
\hline 30 & - & + & - & + & + & - & 0,2 & $0,10^{*}$ \\
\hline 31 & - & + & - & - & + & + & 0 & 0 \\
\hline 32 & - & - & - & + & + & - & 0,4 & 0,22 \\
\hline
\end{tabular}

Märkused. Tabelis on esitatud mustrid, mille olulisus on vähemalt $5 \%$ tasemel. ${ }^{\text {a' }}+^{\prime}-$ on rahul, ' - ' - ei ole rahul. ${ }^{\mathrm{b}}$ ' + ' - kõrgem tase, ' - ' - madalam tase. ${ }^{*}$ - muster on oluline $(p<0,05)$ ka Bonferroni teisenduse korral. 
Klassiópetaja kasvatusstiili tunnuste ja õpilaste kooliga rahulolu vastavuse selgitamine oli teine võimalus määrata õpilaste psühholoogilist resilientsust. Kooliga rahulolu kooskõla õpetaja kasvatusstiiliga analüüsiti kolmanda ja neljanda klassi andmete põhjal, sest viiendas klassis alustab suur osa õpilasi tööd uute õpetajatega ning nende heaolu seostamine klassiõpetaja omadustega oleks võinud anda ebaadekvaatseid tulemusi. Esmalt selgitati õpetaja kasvatusstiili iseloomustavate tunnuste läbilõikelisi seoseid õpilaste rahuloluga. Hii-ruut-testide alusel olid õpetaja toetuse ja hoolivuse kõrge taseme puhul kolmanda klassi õpilased sagedamini kooliga rahulolevad $\left(\chi^{2}(1,443)=6,56, p<0,01\right)$. Õpetaja käitumise ja psühholoogilise kontrolli kõrge taseme korral esines õpilastel sagedamini rahulolematust nii kolmandas klassis (vastavalt $\chi^{2}(1,426)=9,36, p<0,01$ ja $\left.\chi^{2}(1,443)=12,13, p<0,01\right)$ kui ka neljandas klassis (vastavalt $\chi^{2}(1,426)$ $=5,54, p<0,05$ ja $\left.\chi^{2}(1,443)=6,09, p<0,05\right)$.

Järgnevalt tehti KSA, millega uuriti, kuidas on kolmandast neljanda klassini õpilaste kooliga rahulolu stabiilsus ja muutumine seotud klassiõpetaja kasvatusstiili tunnustega. Eelnevate analüüsitulemuste põhjal käsitleti õpetaja toetust ja hoolivust õpilaste rahulolu soodustava tunnusena, aga nii psühholoogilist kui ka käitumuslikku kontrolli rahulolu vähendavate tunnustena. Seega kodeeriti KSA jaoks klassiõpetaja kasvatusstiili iseloomustava muutuja loomisel kolme kasvatusstiili tunnuse muutujad nelja kategooriasse: 1) kõrge toetuse ja hoolivuse tase ning madal psühholoogilise ja käitumusliku kontrolli tase või neist kahest vähemalt ühe tase; 2) kõrge toetuse ja hoolivuse tase ning kõrge psühholoogilise ja käitumusliku kontrolli tase; 3) madal toetuse ja hoolivuse tase ning madal psühholoogilise ja käitumusliku kontrolli tase või neist vähemalt ühe tase; 4) madal toetuse ja hoolivuse tase ning kõrge psühholoogilise ja käitumusliku kontrolli tase. Teise KSAsse kaasatud muutuja neli kategooriat väljendasid õpilaste kooliga rahulolu trajektoore kahe klassi vältel: 1) püsivalt rahulolev; 2) rahulolev kolmandas ja rahulolematu neljandas klassis; 3) rahulolematu kolmandas ja rahulolev neljandas klassis ning 4) püsivalt rahulolematu.

Tulemuste (vt tabel 4) hulgas moodustasid tüübi kooliga püsivalt rahulolevad õpilased, kelle õpetajate kasvatusstiili iseloomustas kõrge toetuse ja hoolivuse tase koos madala käitumusliku ja psühholoogilise kontrolli tasemega (3. muster). Selliste klassiõpetajate õpilaste puhul osutus ka jätkuva rahulolematuse esinemine ebatõenäoliseks kombinatsiooniks (4. muster). Leidus ka tüüp, kuhu kuuluvate õpilaste püsiv rahulolematus esines koos nende õpetajate nii kõrge toetuse ja hoolivuse kui ka kõrge käitumusliku ja psühholoogilise kontrolli tasemega (2. muster). 
Tabel 4. Pikilõikelise KSA tulemused: õpilaste kooliga rahulolu muutumine kolmandast neljanda klassini ja klassiõpetaja kasvatusstiil $(N=426)$

\begin{tabular}{|c|c|c|c|c|c|c|}
\hline \multirow[b]{2}{*}{$\mathrm{Nr}$} & \multicolumn{2}{|c|}{$\begin{array}{l}\text { Kooliga } \\
\text { rahulolua }\end{array}$} & \multicolumn{2}{|c|}{$\begin{array}{c}\text { Klassiõpetaja kasvatusstiili } \\
\text { tunnused }^{\text {b }}\end{array}$} & \multirow{2}{*}{$\begin{array}{l}\% \\
\text { vali- } \\
\text { mist }\end{array}$} & \multirow{2}{*}{$\begin{array}{l}\text { Esinenud ja } \\
\text { oodatud } \\
\text { sageduse suhe }\end{array}$} \\
\hline & 3. $\mathrm{kl}$ & 4. $\mathrm{kl}$ & $\begin{array}{l}\text { Toetus ja } \\
\text { hoolivus }\end{array}$ & $\begin{array}{l}\text { Käitumuslik ja psühho- } \\
\text { loogiline kontroll }\end{array}$ & & \\
\hline \multicolumn{7}{|c|}{ Tüübid } \\
\hline 1 & - & + & - & + & 3,1 & 1,82 \\
\hline 2 & - & - & + & + & 4,2 & 1,55 \\
\hline 3 & + & + & + & - & 19,5 & 1,25 \\
\hline \multicolumn{7}{|c|}{ Antitüübid } \\
\hline 4 & - & - & + & - & 1,9 & $0,38^{*}$ \\
\hline 5 & + & - & - & + & 2,1 & 0,52 \\
\hline
\end{tabular}

Märkused. Tabelis on esitatud mustrid, mille olulisus on vähemalt $5 \%$ tasemel. ${ }^{a}$ ' $+{ }^{\prime}-$ on rahul, ' - ' - ei ole rahul. b ' + ' - kõrgem tase, ' - ' - madalam tase. ${ }^{*}$ - muster on oluline $(p<0,05)$ ka Bonferroni teisenduse korral.

Tüübi moodustasid ka õpilased, kelle rahulolematuse kadumine neljandas klassis esines koos õpetaja kõrge käitumusliku ja psühholoogilise kontrolli tasemega (1. muster). Õpilastel, kellel olid samasuguste omadustega õpetajad, esines rahulolematus neljandaks klassiks antitüübina (5. muster).

Tulemused osutavad, et õpetaja kasvatusstiil võib mõjutada õpilaste rahulolu kooliga. Õpetaja hooliv tegevus näib seostuvat püsivama rahuloluga, kuid kontrolliv käitumine toob kaasa pigem rahulolu muutumise. Selgus, et selliste õpetajate juures on kolmandas klassis rahulolematud õpilased sagedamini muutunud aastaga rahulolevateks. Selline muster võib kajastada õpetaja tegevuse suhtes väljenduvat resilientsust. Huvipakkuv võiks olla tulemus, kus õpilaste püsiv rahulolematus ilmnes koos kasvatusstiili profiiliga, milles on korraga esindatud nii rahulolu soodustavad kui ka seda vähendavad jooned.

\section{Mõistestruktuuri areng ja psühholoogiline resilientsus}

Teisele uurimisküsimusele vastamiseks uuriti, milline on õpilaste mõistestruktuuri arengu seos psühholoogilise resilientsuse avaldumisega. Et selgitada subjektiivselt määratletud NT tasemel põhinevaid resilientsuse ja mõistestruktuuri arengu seoseid, tehti kõigepealt läbilõikelised analüüsid. Esmalt läbiviidud KSAdes ei leitud, et eri klasside mõistestruktuuri 
muutujad oleksid ühegi võimaliku jaotuse korral seotud nendes klassides kooliga rahulolu või NT tasemega. KSAde läbiviimisel, millega selgitati läbilõikeliselt õpilaste mõistestruktuuri seoseid neil esineva kooliga rahulolu ja NT taseme vastavuse vahel, ilmnes neljanda klassi puhul tüüp, kuhu kuulusid mõistestruktuuri tulemuste ülemisse kvartiili jäävate tulemustega õpilased, kelle rahulolematus kooliga esines koos madala NT tasemega $\left(f_{o}=22, f_{e}=12,38, p<0,01\right)$. Seega ei näidanud läbilõikelised analüüsid seost teadusmõistete sagedasema kasutamise ja resilientsuse avaldumise vahel. Neljanda klassi puhul leitud tüüp on selle oletusega vastuolus.

Järgnevalt tehti kaks pikilõikelist KSAd, et selgitada enne komplekssemat analüüsi, millised vastavused esinevad õpilaste mõistestruktuuris eraldi võetult nii kooliga rahulolu kui ka NT taseme muutumisel. Neist esimesse kaasati peale teadusmõistete püsivat kasutamist eristava muutuja ka õpilaste kooliga rahulolu kolme aasta trajektooride muutuja, teise aga kooliga seotud NT tasemete trajektooride muutuja, kus kõrge ja madal NT tase määrati iga aasta kohta muutuja mediaani alusel. Mõistestruktuuri arengu ja kooliga rahulolu vastavuse analüüs ei andnud olulisi tulemusi. Samas ilmnes teises KSAs tüüp $\left(f_{o}=33, f_{e}=23,8, p<0,05\right)$, kuhu kuulusid õpilased, kellel esines kolme aasta vältel nii teadusmõistete kasutamine kui ka kõrge NT tase.

Teadusmõistete püsiva kasutamise ja psühholoogilise resilientsuse avaldumise seose selgitamiseks loodi 11 kategooriaga muutuja, mille 10 kategooriat vastasid tüüpidele, mis leiti õpilaste kooliga rahulolu ja negatiivsete tundeelamuste tasemete seoseid analüüsides (vt tabel 3) ning mis väljendavad kooliga rahulolu ja NT tasemete vastavuse trajektoore kolmel aastal. Kõik juhtumid ülejäänud trajektooridega liigitati 11. kategooriasse. Uus muutuja kaasati KSAsse koos teadusmõistete püsiva kasutamise muutujaga. Analüüsi tulemusena eristus ainukese tüübina väike rühm (4\% valimist) kolmel aastal teadusmõisteid kasutanud õpilasi $\left(f_{o}=17, f_{e}=9,3, p<0,05\right)$, kellel oli peale kooliga rahulolu kolme aasta vältel ka kõrge negatiivsete tundeelamuste tase. Arvestades, et varasemas analüüsis (vt tabel 3, muster 19) leidus ka tüüp, mille liikmetel esines kolmest aastast kahel kooliga rahulolu koos kõrge NT tasemega ning ühel aastal koos madala tasemega, loodi uus kaheväärtuseline muutuja, kus sama kriteeriumit kasutades eristati suurema resilientsusega õpilastena ülejäänud valimist rohkem õpilasi (7\% valimist). Hii-ruut-test $\left(\chi^{2}(1\right.$, $488)=4,47, p<0,05)$ osutas, et ka sel viisil määratud kõrgema resilientsuse tasemega õpilaste hulgas esineb oluliselt sagedamini neid, kes kasutavad teadusmõisteid süstemaatilisemalt. Need tulemused on kooskõlas püstitatud oletusega, et teadusmõistete süstemaatilisem kasutamine kolme 
aasta jooksul iseloomustab õpilasi, kes ühtlasi säilitavad tõhusamalt oma rahulolu kooliga.

Klassiõpetaja kasvatusstiili tunnuste põhjal resilientsuse avaldumise ja mõistestruktuuri arengu seoste selgitamiseks tehti KSA, millesse kaasati teadusmõistete püsivat kasutamist eristav muutuja ning muutuja 16 kategooriaga, mis väljendasid vastavust kolmandast neljanda klassini kooliga rahulolu trajektooride ning õpetaja kasvatusstiili vahel. Analüüsis leiti tüüp $\left(f_{o}=31, f_{e}=21, p<0,05\right)$, mille moodustasid läbi aastate teadusmõisteid kasutanud ja kooliga rahulolevad õpilased, kelle õpetajaid iseloomustas kõrge toetamise ja hoolivuse tase ning madal käitumusliku ja psühholoogilise kontrolli tase. Lisaks leiti antitüüp $\left(f_{o}=12, f_{e}=19,5\right.$, $p<0,05)$, kuhu kuulusid samuti teadusmõisteid kasutavad õpilased, kes olid kooliga püsivalt rahulolevad, kuid kelle õpetajate kasvatusstiilis väljendusid nii rahulolu toetavad kui ka vähendavad tunnused tagasihoidlikult.

Kuigi õpetajate eelistatud tegevusviisid seostusid sellega, kuidas õpilased on kooliga rahul, ei esinenud olulisi mustreid, mis osutaksid mõistestruktuuri arengu ja psühholoogilise resilientsuse esinemise seostele õpetajate kasvatusstiili tunnuste erinevuste alusel. Samas võib esinenud tüüp viidata, et süstemaatilisemalt teadusmõisteid kasutavad õpilased võiksid oma keskkonnas heaolu toetavaid tegureid tõhusamalt ära kasutada.

\section{Arutelu}

Uuringu siht oli selgitada õpilaste kognitiivse arengu ja kooliga rahulolu seoseid. Oletati, et teadusmõistete süstemaatilisem kasutamine võiks soodustada õpilaste toimetulekut ebameeldivate kogemustega ning aidata sel viisil säilitada kooliga rahulolu ka ebameeldivate koolikogemuste puhul. Õpilaste rahulolu häirivate elamuste kirjeldamisel kasutati nende poolt subjektiivselt määratletud negatiivseid tundeelamusi ning ka klassiõpetajate kasvatusstiili tunnuseid.

Esimesest uurimisküsimusest lähtudes uuriti, kuidas on õpilaste rahulolu kooliga seotud nende kogetud NT tasemega ja klassiõpetaja kasvatusstiiliga. Tehtud oletustele vastavalt osutasid tulemused, et negatiivsete elamuste ulatuslikum kogemine väljendub õpilastel üldiselt rahulolematuses kooliga. Need tulemused on kooskõlas varasemate uurimustega, mis käsitlevad heaolu subjektiivse kogemusena, milles kajastuvad indiviidi erinevad asjakohased tundeelamused (Costa \& McCrae, 1980; Diener, et 
al. 1985; Garcia \& Siddiqui, 2009). Samas osutasid klassiõpetaja käitumisviiside analüüsid, et on võimalik osutada koolikeskkonna tahkudele, mida saab üldiselt seostada õpilaste kogetava heaoluga.

Kooskõlas püstitatud oletusega eristus pikianalüüsides ka õpilaste rühm, keda iseloomustas nii püsiv kooliga rahulolu kui ka püsiv kooliga seotud kõrgem negatiivsete tundeelamuste tase. Seega võimaldas andmete pikilõikeline analüüsimine eristada õpilasi, keda võiks teistega võrreldes iseloomustada suurem psühholoogiline resilientsus. Siinkohal näitas klassiõpetajate kasvatusstiili käsitlev pikianalüüs, et koolikeskkonna otseste tunnuste alusel võib samuti täheldada suuremat resilientsust.

Teisele uurimisküsimusele vastamiseks selgitati, milline on õpilaste mõistestruktuuri arengu seos psühholoogilise resilientsusega, mis avaldub kooliga rahulolu säilitamisel. Saadud tulemuste põhjal eristus väiksem rühm õpilasi (7\%), kes olid kolme aasta vältel näidanud üles teadusmõistete kasutamist ning oma kõrgest NT tasemest olenemata säilitanud kooliga rahulolu. Seega on alust arvata, et nende õpilaste puhul võib teadusmõistete kasutamine toetada kooliga rahulolu püsivust. Selliste tunnustega rühma tagasihoidlik suurus võib siin olla isegi ootuspärane: ilmselt võiks arenenum tunnetus üldiselt soodustada paremat toimetulekut ja samas võiks ka niivõrd püsiv ebasoodsate olude esinemine olla pigem ebatavaline.

Siiski ei ole mõistestruktuuri areng uuritud juhtumite puhul ainuke resilientsuse avaldumise allikas. Teadusmõisteid kolmel aastal kasutanud õpilaste hulgas esines kooliga rahulolematuid isikuid ning ebameeldivate kogemuste parem taluvus väljendus korduvalt näiteks ka kümnel õpilasel, kelle mõistestruktuuri testides ei tuvastatud kordagi teadusmõistete kasutamist. Neljandas klassis ilmnes ka läbilõikeline seos teadusmõistete kasutamise ja vähese negatiivsete tundeelamuste taluvuse vahel. Seega ilmneb, et õpilaste psühholoogilise resilientsuse väljendumine võib tugineda erinevatele tunnetuslikele mehhanismidele. Saadud tulemuste põhjal võib mõistestruktuuri areng olla üks vahendeid parema taluvuse saavutamisel.

Varasemas uuringus (Ots, 2010) on kognitiivse arengu panust rahulolu säilitamisel tõlgendatud sisuliselt parema võimekusena oma emotsioone reguleerida (nt ebameeldivate subjektiivsete olukordade tähendust ümber hinnata, leida olukordi, mis pakuvad meeldivaid elamusi, vt Gross, 1998). Siinsed tulemused osutavad muu hulgas, et eraldi võetuna ei seostu mõistestruktuuri areng rahuloluga, küll aga väljendatud negatiivsete tundeelamuste hulga ja intensiivsusega. Arvestades, et teadusmõistete kasutamine hõlmab kogetud nähtuste teadvustamist ja keelesiseseid 
abstraktseid seoseid arvestavat teabe seostamist, võiks kognitiivne areng peale ebameeldivate tunnetega toimetuleku ühtlasi soodustada ka nende märkamist. Seega, kuigi võiks eeldada, et keskkonnaga seotud negatiivsed tundeelamused eeldavad keskkonnas asjassepuutuva tunnuse esinemist, võivad teadusmõisteid kasutavad õpilased sarnastes oludes täheldada enda jaoks enam ebameeldivaid kogemusi kui need, kes kasutavad tavamõisteid.

Suuremat psühholoogilist resilientsust võis täheldada umbes kolmandikul õpilastest, kes kasutasid kõigis klassides teadusmõisteid. Ilmselt ei võimaldanud koolikeskkonna iseloom kõigil kognitiivselt enam arenenud õpilastel korduvalt või üldse mitte oma psühholoogilist resilientsust ka proovile panna. Siiski on selge, et mitte kõik teadusmõisteid süstemaatilisemalt kasutavad õpilased ei säilitanud ebameeldivate kogemuste puhul rahulolu kooliga. Varasemas uuringus (Ots, 2010) oletati, et mõistestruktuuri areng ei pruugi seostuda otseselt õpilaste heaoluga, vaid võib olla vahendatud läbi isiksuse diferentseerumise: mida mitmekesisemalt on indiviid kohastunud toime tulema eri keskkonnaaspektidega, seda harvem võiks talle üldiselt osaks saada ebameeldivaid kogemusi. Siinses uuringus võeti otseselt vaatluse alla indiviidi arengu aspektid, mis kajastuvad muutustena teabe organiseerimisel, kuid ei määra otseselt, mis juhul neid uusi tunnetusviise rakendatakse. Mõtlemise heterogeensusest (Tulviste, 1988) lähtudes võiks oletada, et kuigi indiviid võib kasutada arenguliselt hilisemaid mõistestruktuuri tüüpe, ei pruugi ta seda kõigis oma tegevusvaldkondades ühtmoodi teha. Seega võib õpilane küll testiülesannete puhul demonstreerida teadusmõistete kasutamist, kuid samas kasutada oma probleemidest mõtlemisel endiselt arenguliselt varasemaid teabe organiseerimise viise.

\section{Uuringu usaldusväärsuse piirangud}

Uuringu tulemuste kehtivusse võiks suhtuda ettevaatusega. Kuigi kasutatud kooliga rahulolu küsimustiku (Ots, 2010, vt Ots \& Tago, 2012) puhul on erinevate analüüside käigus leitud nii küsimustiku ülesannete vastuste vahel kui ka teise mõõtevahendi tulemustega (globaalne enesehinnang) teoreetiliselt ootuspäraseid seoseid, ei ole selle mõõtevahendi valiidsus ja reliaablus veenvat kinnitust saanud ning seega vajavad mõõtevahendi omadused edasist selgitamist. Kaasatud valimit saab pidada eesti õppekeelega põhikoolide kohta esinduslikuks. Samas tuleb arvestada, et kuigi andmeid koguti kõigi valimisse kuulunud koolide vastavatest klassidest, on küsimustike täitmine kolme aasta vältel olnud ebaühtlane, mis piirab 
võimalusi analüüsida õpilaste rahulolu kooliga ja selle resilientsust õpilasrühmade kontekstis. Selline analüüs võimaldab paremini mõista kooliga rahulolu kujunemist ja hinnata siin esitatud tulemusi.

\section{Soovitused}

Uuringus leiti, et õpilaste võime säilitada enda heaolu ka ebasoodsates oludes võiks seostuda nende kognitiivse arenguga, kuid leidus ka viiteid sellele, et kognitiivne areng ei toeta tingimata heaolu säilitamist. Samas osutati eespool, et ópilaste heaolu on korduvalt seostatud erinevate hariduseesmärkide saavutamisega. Arvestades, et õppimine saab mõistestruktuuri arengut soodustada (Luria, 1974; Toomela, 2008; Võgotski, 1978), on koolidel otseselt võimalik panustada õpilaste heaolu toetamisse, õpetades neile asjakohaseid mõtlemisoskusi erinevates õppeainetes. Sama tegevus aitab õpilastel ka õpitavaid aineteadmisi paremini mõista ja rakendada. Kuna õpilased ei võta oma uusi mõistestruktuure erinevates valdkondades ühtviisi kasutusele, võiks neid ebameeldivate tunnete ja esilekerkivate probleemidega toimetulekul aidata see, kui neid juhendatakse kasutama arenguliselt hilisemaid mõtlemisvahendeid nii enda isiksuse kui ka oma keskkonna üle arutlemisel. Nii temaatilises õppetöös (nt inimeseõpetuse aines) kui ka õpilaste abistamisel väljaspool tunde võivad selleks sobida enesereflektsiooni ülesanded, simuleeritud olukordade ja rollimängude analüüsid, milles suunatakse õpilasi toimunut ja kaasnenud tundeid teadvustama ning kindlaks tegema sündmuste põhjusi ja enda tegevusvõimalusi. Õpetaja osa võiks siin seisneda õpilaste arutluse kohta tagasiside andmises, mille vältel õpetaja jälgib ja korrigeerib kriteeriume ning järeldusviise, mida õpilased kasutavad. Samuti on oluline pakkuda õpilastele alternatiivseid võimalusi kogemuste mõtestamisel ja aidata märgata probleeme, mis kogemuslike eeskujude järgimisega võiksid kaasneda.

Ôppeasutuste tegevuse tulemuslikkust ja õpilaste toimetulekut selgitatakse sageli rahuloluküsitluste põhjal. Siin kirjeldatud tulemused näitavad, et õpilaste enda heaoluhinnangud võivad kajastada väga erinevaid asjaolusid. Näiteks muutuvad mõned õpilased rahulolematuks teistele tühisena tunduvate asjade pärast, samas kui teised võivad rahulolu väljendada ka üsnagi ebameeldivates oludes. Seega on tähtis, et õpilaste rahuloluhinnangute kogumisel ja tõlgendamisel teadvustataks nende subjektiivset iseloomu ja seotust õpilaste individuaalsete eripäradega ning pöörataks tähelepanu ka teistele tõenditele, mis kirjeldavad õpilase keskkonda ja tema toimetulekut selles. Igapäevatöös õpilastega suheldes saab õpetaja tugineda oma teadmistele õpilase toimetuleku kohta ja tunda huvi, 
kuidas ta ennast koolis tunneb, milliseid positiivseid või negatiivseid läbielamisi on tal ette tulnud. Koolides korraldatavatesse rahuloluküsitlustesse võiks kaasata ülesandeid, mille puhul õpilastel (samuti õpetajatel, lapsevanematel) on võimalik ise kindlaks määrata oma heaolu häirivaid või toetavaid tegureid.

Saadud tulemused on kooskõlas seisukohaga, et koolides saab ja on vajalik määrata tegureid, mille esinemine üldiselt soodustab või takistab õpilastel heaolu kogemist. Kahtlemata võib selliste asjaolude märkamine ja eesmärgipärane kujundamine aidata muuta koolikeskkonda õpilastele meeldivamaks. Siinsed tulemused pakuvad mõningaid osutusi tegevusviiside kohta, mida õpetajad saavad enda puhul teadvustada, et nende abil sihipärasemalt soodustada õpilaste heaolu ning ühtlasi vältida õpilastega suhtlemisel ja nende juhendamisel tegevusi, mis võivad tekitada pigem ebameeldivaid tundeid.

\section{Märkus}

Uuringut toetati Eesti Haridus- ja Teadusministeeriumi grantidega 3-2/ TA5966 ja 10.1-8.1/1794 ning Eesti Teadusagentuuri grandiga IUT03-03.

\section{Kasutatud kirjandus}

Arro, G. (2010). Children's self-reflection and personality and their relationships with cognitive ability and academic success. In A. Toomela (Ed.), Systemic personoriented study of child development in early primary school (pp. 199-224). Frankfurt am Main: Peter Lang.

Arro, G. (2012). Development of self-reflection ability and its relations to scientific concept thinking in mono- and bilingual children: Are bilinguals doing better? In A. Toomela \& E. Kikas (Eds.), Children studying in a wrong language: Russianspeaking children in Estonian school twenty years after the collapse of the Soviet Union (pp. 187-199). Frankfurt am Main: Peter Lang.

Baumrind, D. (1966). Effects of authoritative parental control on child behavior. Child Development, 37(4), 887-907. http://dx.doi.org/10.2307/1126611

Bennet, N. (1976). Teaching styles and pupil progress. Times Educational Supplement (London), 3178, 19-20.

Bergman, L. R., \& El-Khouri, B. M. (2002). SLEIPNER: A statistical package for pattern-oriented analyses (Version 2.1). Stockholm: Stockholm University. Retrived from http://w3.psychology.su.se/sleipner/.

Bergman, L. R., \& Magnusson, D. (1997). A person-oriented approach in research on developmental psychopathology. Development and Psychopathology, 9(2), 291319. http://dx.doi.org/10.1017/S095457949700206X

Bradburn, N. M. (1969). The structure of psychological well-being. Chicago: Aldine. 
Costa, P. T., \& McCrae, R. R. (1980). Influence of extraversion and neuroticism on subjective well-being: Happy and unhappy people. Journal of Personality and Social Psychology, 38(4), 668-678. http://dx.doi.org/10.1037/0022-3514.38.4.668

Diener, E. (1984). Subjective well-being. Psychological Bulletin, 95(3), 542-575. http://dx.doi.org/10.1037/0033-2909.95.3.542

Diener, E., \& Emmons, R. A. (1984). The independence of positive and negative affect. Journal of Personality and Social Psychology, 47(5), 1105-1117. http://dx.doi.org/10.1037/0022-3514.47.5.1105

Diener, E., Larsen, R. J., Levine, S., \& Emmons, R. A. (1985). Intensity and frequency: Dimensions underlying positive and negative affect. Journal of Personality and Social Psychology, 48(5), 1253-1265. http://dx.doi.org/10.1037/0022-3514.48.5.1253

Diener, E., Suh, E. M., Lucas, R. E., \& Smith, H. L. (1999). Subjective well-being: Three decades of progress. Psychological Bulletin, 125(2), 276-302. http://dx.doi.org/10.1037/0033-2909.125.2.276

Eid, M., \& Diener, E. (2004). Global judgments of subjective well-being: Situational variability and long-term stability. Social Indicators Research, 65(3), 245-277. http://dx.doi.org/10.1023/B:SOCI.0000003801.89195.bc

Elliot, A. J., Thrash, T. M., \& Murayama, K. (2011). A longitudinal analysis of selfregulation and well-being: Avoidance personal goals, avoidance coping, stress generation, and subjective well-being. Journal of Personality, 79(3), 643-674. http://dx.doi.org/10.1111/j.1467-6494.2011.00694.x

Emmons, R. A., \& Diener, E. (1985). Personality correlates of subjective well-being. Personality and Social Psychology Bulletin, 11(1), 89-97. http://dx.doi.org/10.1177/0146167285111008

Fallis, R. K., \& Opotow, S. (2003). Are students failing school or are schools failing students? Class cutting in high school. Journal of Social Issues, 59(1), 103-119. http://dx.doi.org/10.1111/1540-4560.00007

Garcia, D., \& Siddiqui, A. (2009). Adolescents' affective temperaments: Life satisfaction, interpretation, and memory of events. The Journal of Positive Psychology, 4(2), 155-167. http://dx.doi.org/10.1080/17439760802399349

Gross, J. J. (1998). Antecedent- and response-focused emotion regulation: Divergent consequences for experience, expression, and physiology. Journal of Personality and Social Psychology, 74(1), 224-237. http://dx.doi.org/10.1037/0022-3514.74.1.224

Hinn, M. (2009). Lapsevanemate ja õpetajate kasvatustegevused - enesekohaste küsimustike kohandamine (Magistriprojekt). Avaldamata käsikiri. Tartu Ülikool.

Hofer, J., Busch, H., \& Kärtner, J. (2011). Self-regulation and well-being: The influence of identity and motives. European Journal of Personality, 25(3), 211-224. http://dx.doi.org/10.1002/per.789

Jonker, E. F. (2006). School hurts: Refrains of hurt and hopelessness in stories about dropping out at a vocational school for care work. Journal of Education and Work, 19(2), 121-140. http://dx.doi.org/10.1080/13639080600667988

Kikas, E. (1998). The impact of teaching on students' definitions and explanations of astronomical phenomena. Learning and Instruction, 8(5), 439-454.

http://dx.doi.org/10.1016/S0959-4752(98)00004-8 
Lee, T., \& Breen, L. (2007). Young people's perceptions and experiences of leaving high school early: An exploration. Journal of Community \& Applied Social Psychology, 17(5), 329-346. http://dx.doi.org/10.1002/casp.887

Lewin, K. (1939). Field theory and experiment in social psychology: Concepts and methods. The American Journal of Sociology, 44, 868-896. http://dx.doi.org/10.1086/218177

Lewin, K., Lippitt, R., \& White, R. K. (1939). Patterns of aggressive behavior in experimentally created "social climates". Journal of Social Psychology S.P.S.S.I. Bulletin, 10(2), 271-299.

Luria, A. R. (1974). Ob istoricheskom razvitii poznavatel'nykh processov. Eksperimental'no psikhologicheskoje issledovanije. Moskva: Nauka.

Luria, A. R. (1976). Cognitive development, its cultural and social foundations. London: Harvard University Press.

Luria, A. R. (1979). Jazyk i soznanije. Moscow: Izdatel'stvo Moskovskogo Universiteta.

Magnusson, D. (2001). The holistic-interactionistic paradigm: Some directions for empirical developmental research. European Psychologist, 6(3), 153-162. http://dx.doi.org/10.1027//1016-9040.6.3.153

Masten, A. S., Best, K. M., \& Garmezy, N. (1990). Resilience and development: Contributions from the study of children who overcome adversity. Development and Psychopathology, 2(4), 425-444. http://dx.doi.org/10.1017/S0954579400005812

McCrae, R. R., \& Costa, P. T. (1996). Toward a new generation of personality theories: Theoretical contexts for the five-factor model. In J. S. Wiggins (Ed.), The fivefactor model of personality: Theoretical perspectives (pp. 51-87). New York: Guilford Press.

Nelson, K. (2003). Making sense in a world of symbols. In A. Toomela (Ed.), Cultural guidance in the development of the human mind (pp. 139-162). Westport, CT: Ablex Publishing.

Ots, A. (2010). Why do some children enjoy attending unpleasant schools? In A. Toomela (Ed.), Systemic person-oriented study of child development in early primary school (pp. 199-224). Frankfurt am Main: Peter Lang.

Ots, A., \& Tago, M. (2012). Bilingual student well-being in submersion education: Changes in self-esteem and school satisfaction during the fourth grade. In A. Toomela \& E. Kikas (Eds.), Children studying in a wrong language: Russianspeaking children in Estonian school twenty years after the collapse of the Soviet Union (pp. 165-187). Frankfurt am Main: Peter Lang.

Raboteg-Saric, Z., \& Sakic, M. (2013). Relations of parenting styles and friendship quality to self-esteem, life satisfaction and happiness in adolescents. Applied Research In Quality of Life. Online publication. http://dx.doi.org/10.1007/s11482-013-9268-0

Rosenberg, M., Schoenbach, C., Schooler, C., \& Rosenberg, F. (1995). Global selfesteem and specific self-esteem: Different concepts, different outcomes. American Sociological Review, 60(1), 141-156. http://dx.doi.org/10.2307/2096350

Rutter, M. (2006). The promotion of resilience in the face of adversity. In A. ClarkeStewart \& J. Dunn (Eds.), Families count: Effects on child and adolescent development (pp. 26-52). New York: Cambridge University Press. http://dx.doi.org/10.1017/CBO9780511616259.003 
Ruus, V-R., Veisson, M., Leino, M., Ots, L., Pallas, L., Sarv, E-S., \& Veisson, A. (2007). Students' well-being, coping, academic success, and school climate. Social Behavior and Personality, 35(7), 919-936. http://dx.doi.org/10.2224/sbp.2007.35.7.919

Schwartz, G., Merten, D., \& Bursik, R. J. (1987). Teaching styles and performance values in junior high school: The impersonal, nonpersonal, and personal. American Journal of Education, 95(2), 346-370. http://dx.doi.org/10.1086/444305

Shiner, R. L., \& Masten, A. S. (2012). Childhood personality as a harbinger of competence and resilience in adulthood. Development and Psychopathology, 24(2), 507528. http://dx.doi.org/10.1017/S0954579412000120

Sieber, S. D., \& Wilder, D. E. (1967). Teaching styles: Parental preferences and professional role definitions. Sociology of Education, 40(4), 302-315. http://dx.doi.org/10.2307/2111938

Skinner, E., Johnson, S., \& Snyder, T. (2005). Six dimensions of parenting: A motivational model. Parenting: Science and Practice, 5(2), 175-235. http://dx.doi.org/10.1207/s15327922par0502_3

Smith, D. E., \& Moore, T. M. (2013). Parenting style and psychosocial outcomes in a sample of Jamaican adolescents. International Journal of Adolescence and Youth, 18(3), 176-190. http://dx.doi.org/10.1080/02673843.2012.682593

Toomela, A. (2003a). Development of symbol meaning and the emergence of semiotically mediated mind. In A. Toomela (Ed.), Cultural guidance in the development of the human mind (pp. 163-209). Westport, CT: Ablex Publishing.

Toomela, A. (2003b). Relationships between personality structure, structure of word meaning, and cognitive ability: A study of cultural mechanisms of personality. Journal of Personality and Social Psychology, 85(4), 723-735. http://dx.doi.org/10.1037/0022-3514.85.4.723

Toomela, A. (2008). Noncognitive correlates of education. Learning and Individual Differences, 18(1), 19-28. http://dx.doi.org/10.1016/j.lindif.2007.07.006

Tulviste, P. (1988). Kulturno-istoritsheskoe razvitie verbalnogo myshlenia. Tallinn: Valgus.

Uibu, K., \& Kikas, E. (2012). Authoritative and authoritarian-inconsistent teachers' preferences for teaching methods and instructional goals. Education 3-13, 42(1), 5-22. http://dx.doi.org/10.1080/03004279.2011.618808

Von Eye, A. (1990). Introduction to configurational frequency analysis: The search for types and antitypes in cross-classifications. Cambridge: Cambridge University Press.

Võgotski, L. S. (1934/1999). Myshlenije i rech. Moscow: Labirint.

Võgotski, L. S. (1978). Mind in society. Cambridge: Harvard University Press.

Walker, J. (2009). Authoritative classroom management: How control and nurturance work together. Theory into Practice, 48(2), 122-129.

http://dx.doi.org/10.1080/00405840902776392

Werner, H., \& Kaplan, B. (1956). The developmental approach to cognition: Its relevance to the psychological interpretation of anthropological and ethnolinguistic data. American Anthropologist, New Series, 58(5), 866-880.

http://dx.doi.org/10.1525/aa.1956.58.5.02a00070 


\title{
Pupil well-being and the development of word meaning structure: Differences in school satisfaction resilience in the context of class teacher parenting style and school-related adverse experiences
}

\author{
Aivar Ots ${ }^{\text {a }}$ \\ a Tallinn University, Institute of Psychology
}

\begin{abstract}
Summary
This article focuses on the relationships between pupil well-being at school and cognitive development. In educational settings, pupil wellbeing has been recognised as an important factor that appears relevant for the achievement of many educational aims, as it has been related to an individual's educational attainments, leaving school early and cutting class (e.g. Jonker, 2006; Fallis \& Opotow, 2003; Lee \& Breen, 2007). In particular, the author's interest lies in exploring relationships between the ability to maintain one's well-being in the context of school-related negative factors and the development of word meaning structure (Toomela, 2003a; Vygotsky, 1934/1999). Pupil well-being at school is conceptualised, in line with the subjective well-being research tradition (Diener, 1984; Diener et al., 1999), as school satisfaction. It represents one of the domain-specific experiences of well-being that relates to the pupil's positive and negative affects in this particular area. The ability to maintain one's school satisfaction in the face of unpleasant conditions at school is defined as the expression of psychological resilience (Rutter, 2006; Shiner \& Masten, 2012).

Better resilience could theoretically be facilitated by the deployment of forms of word meaning structure occurring developmentally later. Specifically, it was hypothesised that better psychological resilience could be obtained by pupils who have begun to organise their knowledge based on the abstract structures coded in language (utilisations of scientific concepts) aside from organising knowledge in accordance with the relations appearing in actual situations (utilising everyday concepts). Thinking in scientific concepts may facilitate resilience by helping pupils
\end{abstract}

1 Institute of Psychology, Tallinn University, Narva Road 29, 10120 Tallinn, Estonia; aivar.ots@ut.ee 
to overcome the obstacles of concrete experiences and to find superficially distinct situations or specific aspects of the environment as relevant for him or her. This could improve the ability to regulate emotion and consequently experience less negative affects.

This longitudinal study of 495 pupils from Estonian primary schools in grades three to five was carried out to investigate the correspondence between the utilisation of scientific concepts and resilience. Here, the longitudinal design was applied in order to gain more profound evidence on, and explore the persistency of, this relationship. However, the deployment of a new word meaning structure does not relate to all actions and areas an individual is engaged in at once. The initial application of scientific concepts could be rather limited and inconsistent as well as include the use of linguistic expressions that are similar to the scientific concept although their further application proves them to be everyday concepts (Kikas, 1998; Tulviste, 1988; Vygotsky, 1934/1999). Therefore, the longitudinal approach was also preferred here, making it possible to indicate pupils who showed rather systematic use of scientific concepts across the three years, and furthermore, to explore their school satisfaction resilience compared to pupils with less systematic use of this type of concept.

Over the three year period, pupil school satisfaction and subjectively specified negative affects at school were assessed using the School satisfaction questionnaire (Ots, 2010) at the beginning of each school year. On the same occasions, pupil use of scientific concepts was measured using the Word meaning structure test (Toomela, 2003b). The characteristics of class teacher parenting style were assessed cross-sectionally based on the Classroom management practices questionnaire (Hinn, 2009; Uibu \& Kikas, 2012), which teachers fulfilled during the data collection in the fourth grade.

The configural frequency analysis method - CFA (von Eye, 1990) was used to analyse the data. In cross-tabulation, the CFA compares expected and observed frequencies in every cell of the categorical variable in order to distinguish types (observed frequency is significantly larger than could be by chance) and antitypes (observed frequency is significantly smaller). Here, the EXACON module in the SLEIPNER 2.1 package (Bergman \& El-Khouri, 2002) was used to specify types and antitypes. An exact test for the comparison of observed frequency with expected frequency was the binomial test.

In order to detect the existence of school satisfaction resilience, first, pupils' school satisfaction was contrasted with their subjectively specified 
negative affects at school as well as the characteristics of their class teachers' parenting style. Cross-sectional analyses showed that a higher level of negative affect among pupils concurs with low school satisfaction in grades four and five. A similar tendency was indicated among pupils in the third grade. An exploration of the relationships between pupil school satisfaction and teacher parenting style showed that a high level of encouragement and affection reflected in classroom management practices appears together with more frequent school satisfaction, whereas higher levels of psychological and behavioural control seem to more often yield dissatisfaction. Even though not evident in cross-sectional analyses, the pupils with higher resilience were detected in longitudinal analyses where, first, the group was distinguished as a type whose members' persistent high school satisfaction appeared together with a constant high level negative affect. Second, the type emerged whose members regained their greater school satisfaction during a year, regardless of their class teachers' disturbing management practices.

Further exploration of longitudinal relationships between the development of word meaning structure and the resilience of school satisfaction indicated that, in line with expectations, a more systematic use of scientific concepts is related to better resilience in the context of subjectively defined negative affects. In addition, pupils who used scientific concepts more systematically appeared more often to be satisfied with their schools if their teacher's parenting style was supportive. Even though this finding does not conform to expectations (i.e. that school satisfaction appears despite disturbing teaching practices), it may do so indirectly by indicating a better ability to take advantage of satisfaction enhancing features in one's environment.

The results appear in agreement with the conceptualisation of subjective well-being and viewing the experience of well-being as relating to a wider range of specific affects. The correlations between subjectively specified negative affects and school satisfaction were indicated in cross-sectional as well as longitudinal analyses. However, class teachers' parenting style, as a feature of the school environment that is not dependent on pupil evaluations, also related to school satisfaction. The interpretation here could be that the school environment has characteristics that can have an effect on the well-being of many pupils, but a more precise understanding of the situation of an individual pupil could be obtained if his or her unique experiences are accounted for.

The present results are also in line with the assumed accord between the development of word meaning and the resilience of school satisfaction; 
it was also evident that not all pupils who persistently use scientific concepts show better resilience. Naturally, the appearance of better resilience can be based on different factors. In addition, a heterogeneity of thinking (Tulviste, 1988) means that the deployment of scientific concepts in a certain area does not have to result in similar developments in other areas. Therefore, the present finding may suggest that the development of scientific concepts could have the potential to support pupil well-being, but this potential is not always realized or is not necessary. Scientific concepts develop extensively at school (Luria, 1976; Vygotsky, 1934/1999). Therefore, the teaching of thinking skills (e.g. categorisation, reasoning, problem solving) and practicing such skills in different subjects may enhance pupil well-being by improving their resilience.

Keywords: psychological resilience, development of word meaning structure, subjective well-being, primary school, parenting styles, negative affect 